\title{
Por que é impossível se ser cético nos dias atuais. Uma breve refutação do Neopirronismo
}

\author{
Roberto Horácio Sá Pereira \\ Universidade Federal do Rio de Janeiro (UFRJ)
}

\begin{abstract}
RESUMO
Duas questôes fundamentais do pirronismo serão abordadas, a primeira é de natureza histórica: seria tal Neopirronismo congruente com o espírito e a letra do Pirronismo original? Nesse particular a resposta não poderia ser mais afirmativa. Distinguindo-se tanto chamada leitura dita "Urbana" quanto da leitura dita "Rústica," não há como negar originalidade à leitura Neopirrônica. Ora, mas uma vez que Neopirronismo se assume como projeto filosófico próprio, ele enfrenta uma segunda questão premente: ele se sustentaria pelas suas próprias pernas? A tentativa de apresentar uma resposta negativa no artigo encontra inspiração em três grandes fontes, são elas: Kant, Wittgenstein e Kripke/Putnam.
\end{abstract}

\section{PALAVRAS-CHAVE}

Pirronismo: Neo-pirronismo; Ceticismo; Oswaldo Porchat.

\begin{abstract}
Two fundamental questions of Pyrrhonism will be addressed, the first is of a historical nature: would such Neopyrronism be congruent with the spirit and the letter of the original Pyrrhonism? In this regard, the answer could not be more affirmative. Distinguishing itself from both the so-called "Urban" reading and the "Rustic" reading, there is no way to deny originality to the $\mathrm{Ne}$ opyrronic reading. Now, since $\mathrm{Ne}-$ opyrronism assumes itself as its own philosophical project, it faces a second pressing question: would it sustain itself on its own legs? The attempt to present a negative answer in the article finds inspiration in three main sources: Kant, Wittgenstein and Kripke / Putnam.
\end{abstract}

\section{KEY WORDS}

Pyrrhonism; Neo-Pyrrhonism; Skepticism; Oswaldo Porchat. 
Homenagem póstuma ao meu grande amigo e mestre

Oswaldo Porchat Pereira

\section{Introdução}

Nas Hipotiposes pirrônicas a célebre passagem que dá azo às releituras do Velho Pirronismo encontra-se em HP I.I3. Sexto distingue claramente dois sentidos possíveis da expressão "crença" ou "dogma":

Quando dizemos que o cético não possui crenças, não estamos usando 'crença' como alguns fazem no sentido mais geral segundo o qual crer é aprovar algo. Por que o cético assente ao aparecer. Por que o cético confere assentimento às afeçōes (pathé) que são o resultado necessário das impressóes sensíveis, e ele não diria, por exemplo, quando sente calor ou frio 'eu não creio que eu não estou com calor ou frio'. Antes, dizemos que o cético não possui crenças, usando 'crença' no sentido em que alguns dizem que crença é assentimento objetos não-evidentes da pesquisa científica a algum assunto não evidente investigado pelas ciências. Por que o filósofo pirrônico não assente a nada que não é evidente. (HP I.I3)

Sexto parece nos dizer aí que o mesmo cético possuiria crenças que, no entanto, estariam fora do escopo da sua $\varepsilon \pi o x n ́$ (epokhé). A distinçáo crucial recai sobre a oposição entre objetos evidentes e não-evidentes (ádela). Nesses termos, poderíamos falar de "crença céticas", da vida comum, em oposição às crenças ditas "científicas". Tal tese é conhecida na literatura como a interpretação Urbana do Velho Pirronismo proposta por Frede. $^{2}$

\footnotetext{
1 Além de passagem supracitada das HP I.I3, encontramos nas H.P. I, 229-30 também indicaçôes de crenças céticas.

2 Cf. Frede, 1987. O que alguns estudiosos Pirronismo no mundo anglófono ignoram é que a interpretação urbana remonta às Preleçôes de lógica de Kant: "Pirro foi o fundador da seita cética, e seus seguidores foram, portanto, chamados de pirrônicos. Esta seita realmente náo duvidou de todas as verdades, mas em vez disso prolongou a investigação e adiou a decisáo. Assim, eles provaram, por meio da dúvida, que as bases para a decisão ainda não estavam completas e, assim, levaram os dogmáticos, que queriam decidir tudo, ao caminho da cautela. Os céticos, no entanto, são também chamados de "buscadores e pesquisadores" zetéticos, e isso porque eles procuraram e inquiriram. Com todas as proposiçóes, entâo, eles não os duvidarâo decisiva nem decididamente, tomarão algo para ser verdadeiro e o aceitarão. Assim, o zetetico náo é aquele que tem a máxima de rejeitar tudo e decidir positivamente sobre tudo, ou mantê-lo cegamente, mas é aquele que reflete sobre suas cogniçóes e as examina. Pirro tinha um certo lema para sua seita: "non liquet". Frente a qualquer um que mantivesse suas proposiçốes com a maior e mais decidida gravidade, ele disparava em oposição: "non liquet". Ainda não está estabelecido. Uma maneira habilidosa e instruída de humilhar algum dogmático arrogante e de mostrar seu lado fraco. Este é um certo lema para toda razáo pura. Náo se deve aceitar nada ao mesmo tempo, mas sim examinar e investigar os objetos, e considerar.” (AA, LB, IX, 2I4, grifos meus) Antecipando Frede, para Kant a $\varepsilon \pi 0 \chi n ́$ pirrônica não visava todas as crenças - não visava especificamente as crenças cotidianas: empíricas, morais, matemáticas ou lógicas, mas exclusivamente as crenças sustentadas pela razáo pura. Assim, para Kant, a vida comum (koinou biou) guiada pelas aparências era prenhe em crenças. Nesses termos,
} 
A ela se opóe a interpretação Rústica do Pirronismo de Barnes (1982), e de Burnyeat (1984/1997) segundo a qual o cético pirrônico viveria inteiramente desprovido de crenças (adoxástos). O velho Pirronismo seria um movimento que visava minar todas as crenças, tanto as do cientista ou do filósofo quanto as do homem comum (idiôtai). A vida comum seria guiada pelas apariçôes "não-doxáticas" (impressóes). Essa leitura tradicional tem origem em Aristocles e Galeno e se estende na história da filosofia ao menos até Hegel (2000). Seguindo Galeno, Barnes denomina tal leitura do pirrônico antigo de interpretação "rústica".

As evidências textuais que apoiam a leitura rústica são abundantes:

1. Parece claro que os dez tropos de Enesidemo visam as crenças ordinárias do homem comum. Além disso, os Cinco Tropos de Agripa parecem indiferentes quanto à natureza das crenças contra as quais eles são dirigidos. Com efeito, Sexto explicitamente inclui entre seus alvos não apenas filósofos e cientistas, mas também "vida ordinária (bios)." (HI, I.I65)

2. Nas Hipotiposes e em outros lugares, Sexto ataca não apenas conceitos filosóficos e científicos, mas também conceitos cotidianos como causação, movimento, lugar, tempo e verdade.

3. Quando nas Hipotiposes Secto quer ilustrar o argumento de que os pirrônicos evitam afirmaçóes positivas e negativas, ele escolhe como exemplos, não afirmaçóes filosóficas ou científicas, mas duas proposiçóes perfeitamente mundanas, "é dia" e "não é dia". (HI, I.I92)

4. A explicação de Sexto sobre vantagem do Pirronismo em relação aos valores - que, abrindo máo desistindo de qualquer crença de que as coisas são boas ou más por natureza minimizaria a inquietação mental -, representa isso como uma vantagem não apenas sobre filósofos ou cientistas, mas também sobre pessoas comuns (idiôtai) ( $\mathrm{Hl}, \mathrm{I}, 27-30)$.

5. Os primeiros críticos do Pirronismo, como Aristocles, que supostamente se encontravam em melhor condição de conhecer o Pirronismo, assumem que estão lidando com uma filosofia que tem a intenção de evitar todas as crenças. De fato, o testemunho crítico inicial sobre o próprio Pirro sugere fortemente que esse já era o objetivo da figura de proa do movimento.

Kant entendia o Pirronismo como um precursor da sua própria filosofia crítica, ou seja, como uma reaçáo contra as crenças dos filósofos ditos dogmáticos. Como me lembrou Plínio Smith em conversa informal, a leitura de Kant parece nos remeter à leitura de Bayle (2005) do Pirronismo encontrada em seu Dictionnaire historique et critique, muito popular em o século XVIII. Bayle atribui dois princípios ao Pirronismo: (i) não temos acesso epistêmico à natureza última e interior das coisas, mas apenas a maneira como eles se nos manifestam (Cf. 2005, verbete: "Pirro", p. 734). Jonathan Barnes denominou a leitura de Frede de interpretaçáo "urbana" do velho Pirronismo (1982, p. 3). 
6. Sexto não apenas caracteriza os Pirrônicos como filósofos que rejeitaram dogmatas - um termo que, como assinala Barnes, frequentemente conota princípios filosóficos ou científicos. Ele também os caracteriza como aqueles que vivem sem crenças, ou seja, "sem doxai - adoxástos" - um termo para crenças que é neutro ou entre crenças técnicas e cotidianas ou realmente sugestivas de crenças cotidianas, e não técnicas.

Entretanto, há também as evidências textuais em apoio a leitura urbana:

I. Sexto usa frequentemente usa qualificaçóes restritivas, como "hoson epi tôi $\log \hat{i} i$ (na medida em que esta é uma questão para a razão?)”. E “physei /pros tên physin /kata tên physin (na natureza das coisas)”, para caracterizar os temas que sobre os quais ele suspende a crença.

2. Em P.H., I.I3 (passagem supracitada), Sexto distingue dois sentidos da palavra dogma e adota posturas nitidamente diferentes em relaçáo aos dois tipos de dogma. Ele diz que, em um sentido, dogma significa apenas "aceitação (eudokein)" de algo, mas, em outro sentido, "assentimento a um objeto não-evidente de investigação científica (tên tini pragmati tôn kata tas epistêmas zêtoumenôn adêlôn sungkatathesin)". E diz que, enquanto o Pirrônico renuncia ao dogma no último sentido, ele mesmo o adota no primeiro sentido.

3. Sexto se manifesta numerosas vezes de forma hostil em relação aos filósofos e cientistas, enquanto se manifesta simpático à vida comum, ou ao homem comum (idiôtai).

O que torna, definitivamente, a interpretação Urbana mais atraente aos olhos do leitor contemporâneo é o princípio da caridade interpretativa. Ela é a única que resolve satisfatoriamente o tradicional problema de $\alpha \pi \rho \alpha$ (apraxia), mostrando de que modo o cético pirrônico poderia viver sua vida. Esse problema ganhou notoriedade na história da filosofia moderna em razão da célebre crítica de Hume:

Mas um pirrônico não pode esperar que sua filosofia tenha qualquer influência constante na mente: ou se tivesse, que sua influência seria benéfica para a sociedade. Pelo contrário, ele deve reconhecer, se ele reconhece qualquer coisa, que toda a vida humana deve perecer, se seus princípios universalmente e firmemente prevalecer. Todo discurso, toda açáo cessaria imediatamente; e os homens permanecem em uma letargia total, até que as necessidades da natureza, insatisfeitas, ponham fim à sua existência miserável. (I992, $\$$ xii, p. I28) 
Entretanto, o problema de $\alpha \pi \rho \alpha$ já era bem conhecido por Sexto uma vez que já tinha sido formulado pelos estoicos. (Cf. AM XI, p. I62-6). E Sexto é bastante contundente com os que propóem tal objeção, afirmando que eles nada mais merecem do que desprezo. (Cf. HP XI, p. I62-3.) Entretanto, como veremos na próxima seção, Sexto não formula nenhum contra-argumento claro contra a objeção. Limitase à lamuria de sempre: os seus adversários sempre ignoravam a "verdadeira natureza" (sic.), do Pirronismo e, em particular, o chamado método das antinomias, confundindo-o na maior parte das vezes com ceticismo da Nova Academia. O problema é: ainda que essa confusão tenha sido frequente, ela sem mais não nos fornece nenhuma solução para o problema da inação.

O Neopirronismo de Porchat suscita duas grandes e prementes questôes. A primeira é histórica: seria o Neopirronismo efetivamente congruente com o espírito e a letra do velho Pirronismo? A minha resposta nesse ensaio é positiva. ${ }^{3}$ Embora a leitura Neopirrônica do velho Pirronismo encontre amparo em apenas duas passagens dos textos de Sexto, ela me parece compatível com o Velho Pirronismo. E como ela se distingue tanto chamada leitura Urbana quanto da Rústica, não há como negar-lhe originalidade. Dedicarei a próxima seção desse ensaio a esse tema.

A segunda questão é se Neopirronismo se sustenta pelas suas próprias pernas como projeto filosófico próprio. Infelizmente, nesse particular meu diagnóstico não poderia ser mais negativo. Os principais artigos Neopirrônicos foram escritos na segunda metade do século passado, quando, segundo Porchat, os filósofos pareciam "cansados com a verdade para além do aparecer". Hoje, com vinte anos de novo século, filósofos genuínos têm uma preocupação intelectual (e política) em tudo oposta: cansamo-nos do descompromisso e do descaso com a "verdade dos fatos". Buscamos sim a verdade como concordância entre palavras e o que transcende o aparecer, ainda que o aparecer seja intersubjetivo. Parafraseando Proust diríamos que os céticos ladram, enquanto a carruagem da metafísica segue a todo o vapor. Fato é: Assistimos, desde Quine, a um reflorescimento da metafísica em todos os diferentes domínios da filosofia. Por essas e outras, o Neopirronismo me parece um anacronismo filosófico, que não enseja nenhuma originalidade, mas acaba por reiterar acriticamente projetos filosóficos bem conhecidos e muito suspeitos, como o Neokantismo e o Neopositivismo (e possivelmente outros mais, como talvez o Pragmatismo norte-americano).

3 Como veremos a seguir, há ao menos duas importantes passagens que sustentam a leitura Neopirrônica. 
Mas não me contento em registrar a ausência de originalidade no projeto. Formulo ainda um argumento de natureza "transcendental", ${ }^{4}$ no espírito original proposto por Strawson nos anos 1950, mas agora contra o Neopirronismo. Meu argumento encontra inspiração em três grandes fontes: Kant, Wittgenstein e Kripke/Putnam.

Buscarei refutar as quatro teses fundamentais do Neopirronismo, quais sejam:

1. O mundo fenomênico seria encerrado em si mesmo

2. O "uso comum da linguagem" seria pautado pela mera afecção (pathos).

3. Palavras da linguagem comum se referem a fenômenos (o que nos aparece intersubjetivamente).

4. Nenhum signo seria indicativo de algo fora do mundo fenomênico, seria meramente rememorativo.

\section{O Neopirronismo como Leitura do Velho Pirronismo}

Retomemos a problemática passagem das Hipotiposes I.I3. Como observamos, os intérpretes ditos "Urbanos sustentam que a $\varepsilon \pi 0 \chi \eta ́$ cética não recai sobre todas as crenças, mas apenas sobre aquelas ditas "científicas", ou seja, cujos "objetos seriam não evidentes". O Pirrônico nada teria contra as crenças comuns. Os Rústicos, em contrapartida, sustentam que que a $\varepsilon \pi 0 x \eta ́$ cética recairia sobre toda e qualquer forma de crença. Os céticos viveriam sem crenças (adoxástos).

À primeira vista, Porchat parece se inclinar a favor da leitura Rústica do velho Pirronismo. Encontramos vários indícios nos seus muitos trabalhos nesse sentido. O mais importante deles me parecer ser a seguinte. Tal como os intérpretes rústicos, Porchat também rejeita textualmente a suposição de que o discurso pirrônico seja tético ou apofântico. Ao enunciar o que quer que seja, o cético nada póe. Ele anuncia sem opinar (adoxástos). Nas suas próprias palavras:

\footnotetext{
Strawson caracteriza essa forma de raciocínio com a seguinte advertência: "A forma desse argumento pode nos induzir ao engano. Não é que, por um lado, tenhamos um esquema conceitual que nos apresente um certo problema de identificaçáo de particulares; enquanto, por outro lado, existem objetos materiais com riqueza e força suficientes para possibilitar a solução de tais problemas. É apenas porque a solução é possível que o problema existe. Assim, com todos os argumentos transcendentais.” (I959, p. 40). Entretanto, ao longo das décadas, o binômio "argumento transcendental" foi compreendido como uma forma de refutaçáo de uma forma de refutação de ceticismo global de inspiraçáo cartesiana ou na melhor das hipóteses de inspiraçáo humeana. Com efeito Hume é apresentado por Strawson como seu oponente. Em uma longa série de trabalhos venho defendendo uma leitura alterativa dos chamados "argumentos transcendentais". Mesmo reconhecendo que tais argumentos seriam ineficazes contra um ceticismo global de inspiraçáo cartesiana ou humeana, sustento que eles são argumentos bem-sucedidos contra uma forma reducionista fenomenista e antirrealista de ceticismo. Cf. Pereira: 2020a; 2020b; 2020c. Minha grande surpresa foi redescobrir no Neopirronismo e seus sucedâneos contemporâneos tal forma de ceticismo.
} 
Dizemos, entáo, que nosso discurso não é tético, como o é o discurso dogmático. Porque este "póe" como real aquilo que diz (cf. H.P. I, I4), assumese como expressão verdadeira de um conhecimento real, pretende-se capaz de transcender-se e de "transcender a empeiría, propóe-se, por assim dizer, como veículo dessa transcendência. Ele quer fazer-nos ver "como as coisas realmente sáo”, para além do "mero" aparecer. Mas, para nós, que questionamos a pretensão apofântica do discurso, que fomos levados à epokhé por esse questionamento, o discurso é mera expressão de nossa experiência, ele diz o seu conteúdo, conta o que aparece. (I993, p. I8I). ${ }^{5}$

Os intérpretes desses textos parecem não ter percebido que um dos grandes feitos filosóficos do Pirronismo foi descobrir e valorizar filosoficamente o uso não-tético, "fenomênico", da linguagem e da argumentação (I993, p. 249). ${ }^{6}$

O cético estaria afirmando algo (provavelmente com uma frase assertiva: “o mel é doce"), mas curiosamente sem pretender que o seu enunciado (o que é dito em sua frase assertiva) seja apofântico, quer dizer, verdadeiro. Como entender uma frase assertiva não apofântica? Não estariamos às voltas com uma contradição em teremos? A única hipótese que vem à mente é entendermos a locução "aparece-me" como um operador cuja função residiria exatamente em suprimir a asserção do que seria um enunciado assertivo. Assim, ao afirmar que "o mel é doce", o pirrônico não estaria

5 Ele reitera tal tese ao longo de inúmeros trabalhos. Conferir também: "o cético está somente anunciando seus fenômenos e suas afecçốes do momento, tanto quanto um "dogmático" quando diz, por exemplo, ser ele próprio um critério de verdade (cf. H.P. I, 4, I5, I87, 190, 197, 203; A.M. VII, 336). O discurso náo-tético dos céticos se faz mera expressáo da fenomenicidade." (I993., p. I52). "Questionado o caráter tético da autorreflexividade da consciência, o Pirronismo não abre nenhum espaço para a emergência do Cogito.” (1993, p. I83). "Porque a epokhé cética diz apenas respeito ao uso tético do discurso, somente este o cético questiona e somente a este ele renuncia. Ele subtraiu ao discurso toda referência a um conhecimento, uma verdade, uma realidade absoluta, ele não tem a pretensão de dizer com suas palavras a verdade sobre a realidade das coisas.” (1993, p. 240) "O cético usa argumentos, mas eles não são téticos, não pretendem estabelecer verdades, suas conclusōes não visam a exprimir realidades, o discurso que propóe não se quer cognitivo. A epokhé confere um índice epistêmico zero também à argumentação." (1993, p.240) "Em verdade, a descoberta pirrônica do uso náo-tético da linguagem é um passo decisivo em sua ruptura com as matrizes tradicionais da racionalidade." (I993, p. 240) "A questáo do uso da argumentação no nível fenomênico se insere na problemática mais ampla do discurso náo-tético e uma das contribuiçôes mais profundas, originais e fecundas da filosofia cética para o pensamento humano parece-nos precisamente residir na maneira com que ela lidou com essa problemática." (1993, p. 242) "A argumentaçáo, enquanto tal, ele a nenhum momento a vinculou ao discurso dogmático e tético." (1993, p. 243)

${ }^{6}$ Mas o que o cético entente aqui por discurso não apofântico? Os Neopirrônicos silenciam a respeito. Nada mais fazem do que reiterar o que é dito por Sexto. No livro quarto do De Interpretationen, Aristóteles diferencia diversos tipos de frases/oraçóes. Ele afirma que toda frase possui um sentido (semantikós), mas nem toda frase apresentam ou póem algo (apophantikós), mas apenas aqueles que pretendem enunciar a verdade. Com efeito, nem todas podem ser apofânticas tais como um pedido, uma ordem, recomendaçóes, etc. Essa distinçáo se tornou clássica e se encontra hoje em qualquer manual de filosofia da linguagem. Na raiz estấo os diferentes modos pelos quais entretemos uma proposição, denominados de açóes discursivas (speech acts). Cf. Aristóteles, 1995. O que Aristóteles denominava de frase apofântica é, grosso modo, o que hoje denominamos de frases assertivas, cujo caráter expressivo reside justamente pretenderem dizer a verdade. Em termos fregeanos, tais frases são expressóes linguísticas de um pensamento (Gedanke) e uma força assertiva. Relativamente ao que essas frases enunciam ou representam, podemos sempre perguntar: o que é dito é verdadeiro ou falso? 
se comprometendo com a verdade da proposição enunciada pela frase "o mel é doce", estaria apenas a relatar como o mel lhe aparece. A dificuldade dessa posiçáo é que, a bem da verdade, primeiro aprendemos (como crianças) a manejar frases assertivas nos comprometendo com a verdade do que enunciamos. Só aprendemos o emprego do operador "aparece-me" depois de termos aprendido o simples uso assertivo da frase sem o operador.

Por outro lado, o Neopirronismo parece coadunar melhor com o a vertente urbana, uma vez que sustenta que os pirrônicos também possuiriam crenças como pessoas comuns. A razão para isso é muito simples: devemos contornar o clássico problema da $\alpha \pi \rho \alpha \xi i \alpha$ (inatividade). Segundo Porchat:

O que nos resta agora, então, depois da epokhe? Nada mais aceitamos nem aprovamos? Se nada mais asserimos como verdadeiro, se renunciamos a conhecer, se em nada mais cremos, se denunciamos todos os juízos apofânticos como dogmas que um pensamento rigoroso e crítico não pode endossar, qual é nossa situação? Viver ainda é possível? Como agir, sem crer? E corno viver, sem agir? Os estoicos repetiram à saciedade essa objeção contra o Pirronismo e Hume a retomou com vivacidade numa passagem de sua obra que se tornou justamente célebre. A epokhé generalizada pareceria condenar-nos inexoravelmente à inação e à morte. A prática sincera da filosofia cética, se acaso possível, encaminharia a um rápido e infeliz desenlace nossa "miserável existência" (cf. Hume, 1983, An Enquiry concerning Human Understanding, p.160), pondo um bem triste fim a nosso itinerário filosófico. (1993, pp. 173174). Tolice e contrassenso... (1993, p. 174).

Em um dos seus primeiros trabalhos, Porchat afirmava:

Pois bem, não é outra a situação em que se encontra o filósofo pirrônico, que a reflexão crítica sobre as doutrinas levou a suspender renovadamente o seu juízo. Exceto obviamente no que respeita às suas expectativas. Nosso jovem filósofo tem ainda, digamos assim, a verdade por horizonte, ele anela por encontrá-la, mesmo se confessa ignorar ainda do que precisamente se trata. Enquanto aquele filósofo mais experimentado, espírito forjado na experiência repetida da epokhé, tem outros horizontes, que a verdade não habita. No que concerne, porém, a definições e decisóes atuais, opçôes e dogmas, é exatamente o mesmo o estado em que se encontram: ambos estão em epokhé. (1993, p. 175)

Ora, o que significa suspender todas as minhas crenças, mas ainda ter a verdade como por horizonte quando tenho que tomar uma decisão: tenho que agir. Com todas as devidas vênias que o Neopirrônico merece, não encontro ai nenhuma resposta para o problema da inação. Digamos que eu tenha que me alimentar, mas suspendo meu juízo sobre as propriedades nutritivas do mel. O que eu faço então, como ou náo? Ter ainda a verdade por horizonte me faria comer do mel? 
Em muitas passagens Porchat se limita a reiterar Sexto:

Náo dispondo de critérios para decidir da realidade ou verdade das coisas, estando em epokhé sobre teorias e doutrinas, não temos como nelas "apoiarnos para regular nossas açóes na vida cotidiana. Compelidos a reconhecer o fenômeno e a ele confinados, é por ele obviamente que orientamos nossa conduta prática no dia-a-dia, tomando-o como critério de ação (cf. H.P. I, 2Is). (1993, p. 193, grifos meus).

O que significa dizer que somos "compelidos a reconhecer o fenômeno e nos deixar orientar por eles?." Como é sabido, o phainómenon cético é o sucedâneo da phantasia kataleptike dos estoicos: ambos seriam evidentes. Entretanto, enquanto a phantasía kataleptike seria uma representaçáo mental, o phainómenon seria antes o próprio objeto intencional de uma atitude proposicional. Pergunta-se: no que isso resolve o problema da inaçáo? Ainda que o phainómenon se me aparente como evidente, o que me levaria a comê-lo ou a evitá-lo? Caso não haja nenhum elemento doxástico no aparecer fica difícil de se solucionar o problema da inação. ${ }^{7}$

Em seu último trabalho Porchat parece mudar de posição:

Aos olhos de Sexto Empírico, que conhece a objeção e expressamente a menciona (cf. AM XI, I62-6), ela é totalmente incorreta. Sexto afirma que ela se deve à incompreensão, por parte dos adversários, do É, por essa razão, diz Sexto, que os dogmáticos propóem as objeçóes da inconsistência e da apraxia (inatividade). Sexto se está referindo à falta de compreensão pelos dogmáticos do famoso método cético das antinomias. E Sexto é bastante duro com os que propóem essas objeçóes, chega a dizer que se deve desprezá-los (cf. HP XI, 162-3). (Porchat, 2016).

A réplica de Sexto recorre ao método das antinomias: a todo discurso se opóe um discurso igual (cf. HP I, 2oI: pantì lógo lógon ison antíketai). Com todas as vênias, mais uma vez, nem o que Sexto diz nem o que Porchat dele interpreta nos fornece qualquer contra-argumento contra a $\alpha \pi \rho \alpha \xi i \alpha$. Continuamos sem saber como o cético não padece por $\alpha \pi \rho \alpha \xi i$ (inação). Mas creio que ambos Pirrônicos e Neopirrônicos deixam pistas. Quais seriam estas pistas?

A menção ao método das Antinomias. Como as antinomias versam sobre crenças ditas dogmáticas, creio que a interpretação mais condescendente deve reiterar que os céticos pirrônicos não possuíam crenças "dogmáticas”, contra as quais sempre

\footnotetext{
Se supusermos que as ações céticas não são intencionais, o problema estaria resolvido. A presença do fenômeno desencadeia várias reaçôes mecânicas no cérebro que podia o indivíduo a agir (pense no tropismo das plantas ou no direcionamento das bactérias anaeróbicas para ambiente pobres de oxigênio. Náo há a menor hipótese de que o velho Pirrônico esteja pensando em algo semelhante. Em todo caso, a conduta não seria intencional. Só há condutas intencionais onde há crenças.
} 
poderíamos opor uma outra crença dogmática de igual força (isosthéneia). Mas eles poderiam possuir crenças não-dogmáticas, ou seja, "crenças céticas”. Nesses termos, o phainómenon também teria uma dimensão doxástica. $\mathrm{O}$ mel aparece-me como doce seria uma crença não-dogmática. E por quê? Porque contra tal crença nãodogmática não podemos avançar uma crença contrária com a mesma força (isosthéneia) ${ }^{8}$ Dito isso, o aparecer doxástico poderia guiar as minhas açóes intencionais e torná-las racionais: Come-se do mel porque se tem fome e acredita-se que o mel aparece doce. Eu até poderia suspender meu juízo sobre a natureza do mel, mas não poderia evitar de acreditar que ele me parece doce. Mas, no que o Neopirronismo se distingue das tradicionais leituras urbanas e rústicas do velho Pirronismo?

Ora, enquanto a leitura urbana sustenta que o cético suspende seus juízos apenas sobre crenças ditas "científicas", e o rústico sobre todas e possíveis crenças, o $\mathrm{Ne}$ opirrônico sustenta que o velho Pirronismo suspende seu juízo sobre "interpretaçôes” metafísicas que tais crenças adquiriram na antiguidade. ${ }^{9}$ Inicialmente, Porchat alegava que nada impediria o Neopirrônico de continuar a utilizá-las no seu sentido usual, incorporando-as ao seu léxico. ${ }^{10}$ Em seus últimos trabalhos, contudo, ele leva a cabo uma reformulação dessas noçóes de realidade, verdade e conhecimento a partir do seu "uso vulgar", a partir da armação interna do mundo fenomênico, sem o tradicional "peso ontológico e epistemológico que lhes confere a metafísica". ${ }^{11}$ Há algumas ao menos duas passagens fundamentais nas Hipotiposes que sustentam a leitura Neopirrônica de Porchat:

Quando investigamos se o objeto é tal como aparece, concedemos que aparece, investigamos não sobre o fenômeno, mas sobre aquilo que se diz do fenômeno; mas isso é diferente de investigar sobre o próprio fenômeno. (H.P. I, I9-20, grifo meu)

\footnotetext{
8 Só quem padece de icterícia não sentiria o mel como doce. "Ninguém certamente ousaria dizer que o mel não é sentido como doce pelos sãos ou que náo é sentido como amargo pelos que têm icterícia" (cf. H.P. II, 2II)." "A cor branca, por exemplo, não é experienciada do mesmo modo por quem tem icterícia, por quem tem os olhos injetados de sangue e por quem tem uma condição natural (pois suas disposiçóes sáo dessemelhantes e por essa causa (par' hèn aitían) a um aparece amarelo, a outro avermelhado, a outro branco); mas aos que estão numa mesma condição, isto é, aos sãos, somente aparece branco. (cf. A.M. VIII, 22I-2)" Cf. Porchat 2007 , p. 183 .

9 Essa leitura Neopirrônica do velho Pirronismo encontra-se em toda a obra de Porchat. Por isso, me dispenso o trabalho de mencionar passagem por passagem aqui. Como veremos mais à frente, é exatamente dessa forma que o Neopositivismo entendia problemas metafísicos clássicos.

10 "Na descriçâo de sua experiência do mundo, mormente quando questôes filosóficas estão em pauta, o cético preferirá abster-se do vocabulário da verdade, realidade e conhecimento, porque não esquece quấo prenhes estão essas palavras dos significados filosóficos que uma tradição secular lhes associou. Sem isso, as palavras seriam, em si mesmas, inocentes, e, na prática cotidiana, o cético não se inibirá de usá-las, seguindo o uso comum. Porque "verdade", "realidade", "conhecimento", em seu uso vulgar, remetem primordialmente à armação interna do mundo fenomênico, não têm peso ontológico ou epistemológico.” (Porchat, 1993, p. 199)

${ }^{11}$ Cf. 1993, p. 199. Retomaremos esse ponto na seção seguinte.
} 
Mas, querer estabelecer que os fenômenos não apenas aparecem, mas são também reais, é próprio de homens que não se contentam com o que é necessário para o uso da vida, mas se esforçam por arrebatar também o possível (cf. A.M. VIII, 368, grifo meu).

Segundo o Rústico, deveríamos entrar em epokhé face a todas as nossas crenças. Segundo o Urbano, deveríamos entrar em epokhé face apenas às nossas crenças filosóficas. Mas o Neopirronismo seria um ceticismo sobre a metafisica clássica: um ceticismo sobre as "interpretaçóes" ou "conotaçôes" que os metafísicos de então fizeram do fenômeno. Dito isso, deveríamos suspender nossos juízos sobre nenhuma das nossas crenças, mas apenas das nossas crenças ditas "filosóficas", mas apenas os juízos sobre a "leitura metafísica de tais crenças".

\section{O Neopirronismo como Projeto Filosófico}

Porchat define seu Neopirronismo nos seguintes termos:

Entendo por neopirronismo uma doutrina que, consoante embora com a filosofia do aparecer e preservando grande coerência com as 'intuiçóes' do velho Pirronismo se empenha em repensá-lo, atualizá-lo e prolongá-lo, na convicção de que ele pode corresponder plenamente às necessidades filosóficas dos nossos dias" (2007, p. 174).

O Neopirronismo como projeto filosófico está centrado na reformulação dos conceitos tracionais de verdade, realidade e conhecimento da metafísica e da epistemologia em "termos fenomênicos" de forma "consoante aos ditames da velha filosofia do aparecer", o Pirronismo antigo. A ideia norteadora é clara e distinta: tratase de um ceticismo frente à metafísica clássica que abraça uma epistemologia fenomenista essencialmente antirrealista. Segundo Porchat:

$\mathrm{Na}$ descrição de sua experiência do mundo, mormente quando questóes filosóficas estão em pauta, o cético preferirá abster-se do vocabulário da verdade, realidade e conhecimento, porque não esquece quão prenhes estão essas palavras dos significados filosóficos que uma tradiçáo secular lhes associou. Sem isso, as palavras seriam, em si mesmas, inocentes, e, na prática cotidiana, o cético não se inibirá de usá-las, seguindo o uso comum. Porque "verdade", "realidade", "conhecimento", em seu uso vulgar, remetem primordialmente à armação interna do mundo fenomênico, não têm peso ontológico ou epistemológico. (1993, p. 199)

É no interior do mundo fenomênico que distinguimos entre "real" e imaginário ou fictício, "verdadeiro" e "falso", sonho e vigília (o argumento cartesiano do sonho 
é estranho à problemática pirrônica), “conhecimento" e ignorância ou conjectura. (1993, p. 200)

Limitar-me-ei a analisar a ideia de um realismo cético porque dela depende a noção de verdade cética e a noção de conhecimento cético. À primeira vista, o próprio binômio pode soar não familiarizado como um contrassenso: como algum cético poderia ser ao mesmo tempo um realista? Mas não nos afobemos em condenar antes de julgar. Suspendamos o juízo provisoriamente.

Porchat formula seu realismo fenomênico a partir de uma leitura fenomenista do Quarto Paralogismo da Crítica. Kant, nas palavras de Porchat, teria sido o primeiro a mostrar que podemos entender "realidade" de uma forma supostamente não metafísica ou transcendental:

Kant foi o primeiro filósofo a ter mostrado - e o fez explicitamente - que a rejeiçấo do realismo metafísico (que ele chamou de "transcendental") não implica necessariamente a recusa de toda postura que se possa legitimamente chamar de "realista". (2007, p. I82)

O realismo transcendental, considerando espaço e tempo como dados em si mesmos, independentemente de nossa sensibilidade, interpreta as aparências externas como coisas-em-si, existindo independentemente de nós e de nossa sensibilidade, eminentemente fora de nós. Essa suposição errônea de que, para serem externos, os objetos dos sentidos devem ter uma existência por si mesmos e independentemente dos sentidos leva, no entanto, o realista transcendental a descobrir que, sob esse ponto de vista, nossas representaçóes sensoriais são inadequadas para estabelecer a realidade dos objetos. E o realista transcendental é assim conduzido a "fazer o jogo do idealista empírico". (2007, p. I83, grifos meus).

Vemos Kant endossar plenamente os velhos argumentos de Sexto Empírico contra a concepção dos objetos externos como realidades absolutas e contra a pretensáo de dar conta de nossa alegada apreensáo delas por meio só de nossas representaçôes. $(2007 \text {, p. } 183)^{12}$

Prima facie, a história da filosofia pouco me importa aqui. Entretanto, há um equívoco sobre a leitura de Kant que deve ser mencionado porque ele nos remete diretamente ao Neokantismo de Marburg. Com efeito, Kant nunca afirmou que seria errônea a suposição de que para serem externos os objetos dos sentidos deveriam possuir uma existência em si mesma independente dos sentidos. Pelo contrário, na segunda edição da sua Crítica, Kant não deixa sombra de dúvidas de que para ser externos os objetos que intuímos no espaço também devem existir como coisas-em-

${ }^{12}$ Sempre sustentei que Neopirronismo era uma forma de filosofia transcendental. Cf. Pereira 2004. 
si (noumena em sentido negativo). Essa é a essência da célebre Refutação do idealismo ( $K r V$, B 275-279). A consciência da existência de coisas-em-si fora de mim que me aparecem como entidades permanente no espaço, seria uma condição necessária para a consciência que tenho da própria existência determinada no tempo. Nesses termos, Kant teria mudado de opinião entre as duas edições. Ele nega peremptoriamente ter mudando de posiçáo. Se isso for correto, Kant jamais acreditou que o mundo fenomênico fosse fechado em si. ${ }^{13}$

Não encontrei na obra de Porchat uma única referência ao Neokantismo. Náo tenho dúvidas, contudo, que ele lê as passagens do Quarto Paralogismo à luz do Neokantismo de Marburg:

Pois agora é função do conhecimento construir e constituir o objeto, não como um objeto absoluto, mas como um objeto fenomenal, condicionado por essa mesma função. O que chamamos de ser objetivo, o que chamamos de objeto da experiência, só é possível se pressupusermos o entendimento e suas funçóes a priori da unidade. Dizemos então que conhecemos o objeto quando alcançamos a unidade sintética na variedade da intuiçáo. (Cassirer, 1957, p. 5, ênfase minha) ${ }^{14}$

Pois não há visão e nada visível que não esteja em algum modo de visão espiritual, de ideação. Uma visão e uma coisa vistas fora desta "visão", uma sensação "nua" que precede toda a formação, é uma abstração vazia. O "dado"

${ }^{13}$ Há inúmeras passagens na obra de Kant que corroboram o que estou dizendo. Limito-me a citar três: "Mas se tomarmos o mundo como um fenômeno, isso prova algo que não é mera aparência" (AA, I8: 305, R5356; ênfase adicionada). "Precisamos determinar algo no espaço para determinar nossa própria existência no tempo. Aquela coisa fora de nós é assim apresentada antes dessa determinação como um noúmenon" (AA I8: 4I6, R5984, ênfase original). Mas a evidência textual mais significativa se encontra na primeira Crítica: "Quanto às aparências do sentido interno no tempo, ele não encontra dificuldade em coisas reais, de fato, ele até mesmo afirma que esta experiência interna e fornece por si só prova suficiente da existência real de seu objeto (em si mesmo) conjuntamente com a determinação temporal”. (B 519 ; grifo meu). Quando Kant afirma que o realista transcendental concebe o espaço e o tempo e tudo mais que neles se encontra (como a matéria) como coisas-emsi e a isso contrapóe seu realismo empírico, que toma o mesmo espaço e tempo como fenômenos, ele não está de modo algum dizendo que a realidade se reduza ao que nos aparece aos sentidos e ao entendimento (reducionismo fenomenista). O que o realista empírico kantiano afirma é que a matéria nada mais é do que a forma como as coisas-em-si se manifestam imediatamente ao nosso aparato cognitivo. Em outras palavras, a corporeidade é a forma como nós humanos apreendemos imediatamente as coisas em si que existem fora e independentemente de nós.

${ }^{14}$ Inúmeras outras passagens da obra de Cassirer exprimem o mesmo fenomenismo antirrealista: "O que quer que seja coerente com as condiçôes materiais da experiência (sensação)" - então Kant formula o segundo dos postulados do pensamento empírico - "é real". Essa coerência, no entanto, é criada e sua particularidade e caráter formal determinados pelas leis gerais do entendimento, das quais todas as leis particulares da natureza são meramente especificaçôes". (Cassirer 1957, p. II). "Aplicado ao problema da percepçâo, isso significa que, quando estamos preocupados em distinguir o mundo da consciência pré-científica das determinaçóes construtivas da cogniçáo científica, podemos considerar a própria percepçáo como algo relativamente simples e imediato. Em relação a essas determinaçóes construtivas, pode aparecer como um dado simples, como algo "dado antecipadamente". Mas isso de maneira alguma nos priva da possibilidade ou nos isenta da obrigação de reconhecê-la em outro contexto como algo completamente mediado e condicionado". (Cassirer 1957, p. I0). 
deve sempre ser tomado em um aspeto definido e assim apreendido, pois é esse aspeto que primeiro lhe dá significado. (Cassirer 1957, p. 134)

Além dos Neokantianos, quem melhor resume essa tese Neopirrônica é o Neopositivismo. Com a palavra Schlick:

Para encontrar um equacionamento da controvérsia acerca do "Realismo" é de suma importância chamar a atençáo do físico para o fato de que $o$ seu mundo externo não é coisa senão a natureza que nos rodeia na vida de cada dia, e não o "mundo transcendente" dos metafísicos (Schlick, 1973, p. 64, grifos meus).

As semelhanças do Neopirronismo com o Neopositivismo náo terminam por aí. Há uma passagem lapidar na obra de Porchat a respeito:

Imaginemos filósofos reunidos alegremente a tomar chope, em torno de uma mesa de bar (um bergsoniano talvez, um hegeliano, um kantiano, um berkeleyano, um aristotélico, por exemplo, e, de contrapeso, um cético). E suponhamos que não estejam a falar de filosofia. Suas grandes divergências filosóficas não os impedem obviamente de se entenderem entre si e com o garçom sobre um sem número de coisas, de eventualmente se porem de acordo sobre assuntos vários (como a temperatura ou a crise econômica), de descreverem de modo idêntico objetos e eventos familiares a seu redor, como o fazem homens quaisquer na "praça do mercado". Eles e todos tranquilamente reconhecemos como óbvio que experiências da vida cotidiana são objeto de descriçôes consensuais por parte de filósofos que, no entanto, dividem sérias diferenças de doutrina. Porque se trata dos "fenômenos comuns" que a todos se impóem irrecusavelmente e que a filosofia jamais cogitou de recusar (nenhum filósofo idealista jamais negou que Wittgenstein usasse cuecas sob as calças). (1993, p. I8I)

Mas, se esses filósofos todos dizem do mesmo modo ou de modo muito semelhante os fenômenos, eles divergem consideravelmente quanto ao que teriam a dizer acerca dos fenômenos (exceção feita para o cético, que nada teria a dizer). Suas diferentes doutrinas oferecem leituras incompatíveis dessa experiência comum que eles consensualmente descrevem, elas interpretam os fenômenos de diferentes maneiras. Não nos seria, talvez, difícil imaginar como cada um daqueles filósofos dogmáticos comentaria, do interior de sua particular filosofia, um enunciado banal qualquer sobre a sua experiência atual ("esse chope veio quente", digamos). Cada um deles certamente rejeitaria as interpretaçóes de todos os outros e pretenderia ser a sua própria leitura filosófica do fenômeno comum em questáo a única capaz de dele dar integralmente conta. A discordância doutrinária entre eles é total, tanto quanto seu acordo "pré-filosófico" sobre o fenômeno e como descrevê-lo é, suponhamo-lo, inteiro (I993, p. I8I-I82). 
Ora, esse experimento mental é análogo nos mínimos detalhes aos famosos experimentos mentais propostos pelos vienenses. Quem não se lembra do famoso experimento mental de Carnap no qual dois geógrafos/filósofos são enviados à África para averiguar a existência de uma dada montanha:

Dois geógrafos, um realista e um idealista, que sáo enviados com o fim de verificar se uma montanha que se supóe existir em algum lugar na África é somente lendária ou realmente existe, chegarão ao mesmo resultado (positivo ou negativo). Na física, assim como na geografia, existem certos critérios para o conceito de realidade nesse sentido - queremos chamá-lo de "realidade empírica" - que sempre conduzem a resultados definitivos náo importando a convicçáo filosófica do investigador. Os dois geógrafos chegaráo ao mesmo resultado náo apenas sobre a existência da montanha, mas também suas outras características, a saber, a posiçáo, a forma, a altura, etc. Em todas as questóes empíricas, há unanimidade. Logo, a escolha de um ponto de vista filosófico não tem nenhuma influência no conteúdo da ciência natural (isso não significa que esse ponto de vista náo poderia ter alguma influência prática sobre a atividade do cientista). (Carnap, I980, p. I58-159). ${ }^{15}$

Enquanto geógrafos, afirmava Carnap, eles forçosamente chegariam a uma conclusão comum: a montanha é real ou lendária, porque assim lhes aparece à visão e ao intelecto. Mas suponhamos que além de geógrafos eles seriam (pobres coitados) metafísicos. Assim que deixassem a geografia de lado e se pusessem a filosofar, surgiria a controvérsia insolúvel: a montanha que lhes aparece como real seria em si mesma real de forma absoluta? A ideia é exatamente a mesma: a realidade da montanha se reduz ao que aparece às pessoas. ${ }^{16}$

Mutatis mutandis, os filósofos à mesa de um bar se póem facilmente de acordo acerca da realidade acerca sem-número de coisas como, por exemplo, o chope lhes aparece gelado, o dia lhes aparece quente, o país passa por dificuldades econômicas etc. Tal acordo seria possível, segundo o Neopirrônico uma vez que, com base no uso comum da linguagem, eles poderiam reconhecer a partir do seu pathos, se está ou não fazendo calor, se o chope está gelado e assim por diante.

Entretanto, suponhamos que além de pessoas da vida comum, tais pessoas tivessem uma graduação em filosofia. Eles então deixariam de lado a vida comum se

\footnotetext{
${ }^{15}$ Por volta desse período, Carnap viria a redigir o seu célebre Aufbau. Cf. 1928.

${ }^{16}$ Cf. "Sexto Empírico, numa passagem (A.M. VIII, 8) em que uma vez mais menciona o heraclitismo de Enesidemo (em H.P. I, 210), ele atribui a esse filósofo cético - que não parece, aliás, considerar assim táo cético - a ideia de que a filosofia cética é caminho para a de Heráclito), nos relata: "Enesidemo, com efeito, afirma uma diferença entre os fenômenos e diz que uns dentre eles aparecem em comum a todos, outros a alguém em particular, dos quais são verdadeiros os que aparecem em comum a todos, falsos os que não são assim" (2007, p. 210).
} 
poriam a filosofar. Eles passariam a indagar agora se o fato de o chope lhes aparecer gelado corresponderia ao modo como o chope realmente se encontra para além do aparecer coletivo e intersubjetivo. Aqui começaria a controvérsia insolúvel da velha metafísica. Segundo Porchat, alguns "atribuiriam realidade ao fenômeno" (os realistas), outros "a negarão" (idealistas). Assim, se enquanto cidadáos comuns, nossos alegres filósofos estariam discutindo acerca da realidade fenomênica: é verdade que o chope nos aparece gelado porque tal fato concordaria com os fenômenos, ou seja, com que aparece intersubjetivamente para nós! Entretanto, enquanto metafísicos, a sua controvérsia não giraria mais em torno de nenhuma do aparecer intersubjetivo, mas sobre o que lhe subjaz.

Com a exceção da leitura do velho Pirronismo, as concordâncias do Neopirrônico com o Neopragmatismo também são dignas de nota. Segundo, o Neopirrônico, "não é desinteressante lembrar aqui o que nos diz Rorty ao comentar o behaviorismo epistemológico de Quine e Sellars: "É a suposição de que a filosofia não terá mais a oferecer do que o senso comum (complementado pela biologia, história etc.) sobre conhecimento e verdade" (cf. Rorty, 1980, p.176 - 2007, 2006-2007).

É nesse contexto que devemos entender a oposição Pirrônica e Neopirrônica entre signos rememorativos e signos indicativos. Segundo Sexto:

Propomos dedicar toda a nossa investigação e crítica não ao sinal rememorativo, pois este é visto geralmente por todas as pessoas comuns como úteis, mas ao indicativo, pois este foi concebido pelos filósofos dogmáticos e pelos lógicos ... Portanto, não estamos atacando os preconceitos comuns da humanidade, nem colocando a vida comum de cabeça para baixo ao afirmar que náo existem signos como alguns afirmam caluniosamente de nós. Pois, se nós estivéssemos abolindo todos os signos, talvez estivéssemos atacando a vida ordinária e toda a humanidade, mas como é, nós mesmos somos da mesma opiniáo e inferimos o fogo da fumaça, e uma ferida anterior de uma cicatriz." (H.I 2.156-8)

Segundo o Neopirrônico:

A noção de signo é discutida amplamente em H.P. I, 97-I33 e A.M. VIII, I4I299. Os céticos suspendem o juízo sobre a existência dos signos "indicativos" propostos pela filosofia "dogmática", mas reconhecem plenamente os signos "rememorativos", com base na conjunção constante entre "fenômenos" de que se tem experiência na vida comum, cf. H.P. I, Ioo-2; A.M. VIII, I5I-8. (Porchat, 1993, p. 154)..$^{17}$

${ }^{17}$ Coube aos estoicos o mérito de terem criado a teoria da significação mais elaborada da antiguidade. Consideram signo o objeto que póe em relaçáo três entidades: um significante ou som, uma proposiçáo ou lekton e o objeto 
A ideia não poderia ser nem mais clara nem distinta: nunca devemos tomar os fenômenos com um indicativo de algo que lhes transcenda ou subjaza, mas apenas como rememoração a outro fenômeno quando houver entre eles uma conjunção constante. Não deve ser surpresa a ninguém como uma má ideia reaparece várias vezes na história da filosofia, ainda que com outra roupagem, como no Empirismo clássico de Hume e mais uma vez no Neokantismo de Cassirer e a razão é óbvia: se o mundo fenomênico é fechado em si mesmo, nada pode indicar nada além, mas apenas nos evocar à memória algo outros fenômenos:

Heinrich Hertz é o primeiro cientista moderno a efetuar uma mudança decisiva da teoria da cópia do conhecimento físico para uma teoria puramente simbólica. Os conceitos básicos da ciência natural não aparecem mais como meras cópias e reproduçôes de dados materiais imediatos; ao contrário, são representados como projetos construtivos do pensamento físico - e a única condição de sua validade e significância teórica é que suas consequências lógicas devem sempre estar de acordo com os dados observáveis. (Cassirer 1957, p. 20, grifos meus)

A tese metafísica tácita (nunca assumida) é cristalina: o real é o que aparece da mesma forma a vários agentes antes que comecem a filosofar. Comentando uma publicação de Chisholm 194I, Porchat reconhece explicitamente a proximidade do seu Neopirronismo com o Neopositivismo e o Neopragmatismo:

(...) as três contribuiçóes mais significativas da doutrina sextiana para o pensamento empirista: uma teoria "positivista e comportamentalista" dos signos,

que é uma realidade exterior referida pelo signo. No século II, Galeno vai originar uma outra tradição no estudo dos sinais ou sintomas, a da semiótica médica, disciplina ainda hoje em uso nalguns currículos universitários, sob o nome de semiologia clínica. Médico famoso em Pérgamo, e mais tarde em Roma, constitui a fonte mais importante para conhecer as escolas médicas da antiguidade, pois embora afirmando náo pertencer a nenhuma, apresenta com notável clareza nos seus tratados o estado dos debates entre "empíricos", "dogmáticos" e "metódicos". Sendo difícil situá-lo numa das escolas, é certo que aceita como sua a divisão da medicina em três grandes ramos: a semiótica, a terapêutica e a higiene. Retomando Sexto, também um médico, Galeno reconhece que à arte do médico são fundamentais as operaçóes semióticas, que atuam por observação e rememoraçâa, porque o signo deve ser interpretado por aquele que pode atribuir-lhe significado. Quanto à semiótica, Galeno diz que encerra duas vertentes, o diagnóstico dos fenômenos presentes e o prognóstico dos fenômenos futuros; e isto fá-lo a semiótica, arte totalmente empírica, recorrendo à observação e à memória. Signos para o médico são todos os sintomas de doença, que Galeno define como algo contra a natureza. Há depois três tipos de sintomas. Diagnósticos quando, a partir dos sintomas, se declara um estado; prognósticos quando, a partir de certos signos, o médico prevề o que se vai passar; e terapêuticos quando a observação dos sinais provoca a rememoração de um tratamento. $C f$. Fortuna 200I. Os signos rememorativos também náo passaram desapercebidos por Kant. No seu texto pós-crítico intitulado "Antropologia do ponto de vista pragmático", Kant discrimina entre signos artificiais, naturais e prodigiosos. Entre os primeiros contam-se os signos fisionómicos (signos mímicos que são parcialmente naturais); a escrita e a pontuação; os signos sonoros; a heráldica; signos de função, caso dos uniformes; decoraçóes; e signos de infâmia, caso das marcas gravadas nos criminosos. Os signos naturais, pela relaçáo que estabelecem com o seu objeto, podem ser demonstrativos (todos os sintomas), rememorativos (túmulos e mausoléus, pirâmides, ruínas, relevos vulcânicos, que são memória de coisas ou estados passados), e prognósticos (que dirigem a atençáo para acontecimentos futuros, caso da astronomia, de certos sintomas que revelam o curso de uma doença, etc.). $C f$. Kant, 2000, capítulo quarto parágrafo 39. Importante observar, contudo, que mesmo reconhecendo a existência dos signos rememorativos, Kant nunca nega a existência dos indicativos ou demonstrativos. 
uma discussão do fenomenismo e da relação entre este e as pretensões do senso comum ao conhecimento e, em terceiro lugar, uma exposição da controvérsia sobre o princípio da extensionalidade na lógica. A teoria sextiana dos signos teria sido "uma clara enunciação dos princípios essenciais do positivismo, pragmatismo e behaviorismo" (I94I, p. 373). O autor entende que "a discussão de Sexto sobre nosso conhecimento do mundo exterior sugeriria uma epistemologia puramente fenomenista (1941, p. 376. 2007, p. 290)

A primeira conclusão que retiro desse ensaio é que o Neopirronismo nada tem de original. O Neopirronismo nada mais faz do que reiterar teses fenomenistas e antirrealistas do século vinte, como o Neokantismo, Neopositivismo, e o Neopragmatismo hoje esquecidas tanto por inúmeras inconsistências conceituais como também pelo fato de não mais responderem aos problemas filosóficos dos nossos tempos. A questão fundamental não é o imperativo Neopirrônico ("Ainda é preciso ser cético!”, título de um dos trabalhos Neopirrônicos de Porchat), mas a indagação cética a respeito do próprio imperativo: ainda é possível sermos céticos? Com todas as vênias: Não, hoje é impossível sermos céticos. Em 1993, Porchat dizia:

Suponhamos alguém que, cansado das infindáveis disputas filosóficas e consciente da impossibilidade de encontrar um critério aceito para resolvê-las, tenha renunciado ao filosofar. E que tenha imergido, entâo, de corpo e alma na vida comum e se tenha reencontrado como um homem comum e qualquer. (1993, p. 96, grifo meu)

Nossa época está cansada de verdades... O intelectual contemporâneo tende fortemente ao ceticismo. Se não o confessa, isso se deve táo-somente às conotaçôes perversas que a ignorância generalizada sobre o Pirronismo, inclusive em boa parte dos filósofos, associou ao termo. Eis porque relembrar o Pirronismo é preciso. (1993, p. 2II, grifo meu)

Com todas as vênias, por infindáveis que sejam, á da própria natureza da filosofia ingressar e tomar partido nas infindáveis disputas acadêmicas ainda que saibamos que muitas delas são insolúveis. Mas como procede o Neopirronismo? Ele deliberadamente se recusa à própria essência do próprio jogo filosófico! Ele busca pairar sobre as disputas como sem que nenhuma delas lhe disse respeito.

Em 2020, afirmo hoje por conta e risco próprio em nome de muitos da nossa comunidade acadêmica que estamos cansados é com o descompromisso e descaso com a verdade com a maior das virtudes epistêmicas. Com o reflorescimento da velha metafísica, buscamos saber sim sobre a natureza última das coisas: Qual seria a natureza última da mente? Qual seria a natureza da causalidade? O que são leis da natureza? Seria a matéria a realidade última do universo? 


\section{A Refutação do Neopirronismo}

Passo agora a arrolar várias teses Neopirrônicas. Com todas as devidas vênias ao meu querido Porchat, ao meu juízo são todas falsas sem exceção.

I. O fenomenista antirrealista que supóe que o mundo fenomênico seria fechado em si mesmo: "É no interior do mundo fenomênico que distinguimos entre "real" e ou fictício, "verdadeiro" e "falso" (1993, p. 200).

2. Ademais, o a sua garantia desse fechamento fenomênico nada mais seria do no "uso comum da linguagem". Seria a partir desse uso vulgar que eles poderiam reconhecer a partir do seu pathos.

3. Palavras da linguagem comum se referem aos fenômenos. ( $C f$. 1993, p. 210).

4. Nenhum signo é indicativo de nada fora do mundo fenomênico, mas apenas rememorativo.

São inúmeros os problemas que o Neopirrônico enfrenta. Enumero os três principais:

I. Como ele pode se certificar que o que lhes aparece o faz em um uma ordem temporal determinada?

2. Como ele pode ser certificar que o que lhe aparece agora é numericamente idêntico ao que lhe aparecia há algum tempo atrás?

3. Será que "uso da linguagem comum" se comporta tal como Neopirrônico sustenta? Palavras se referem usualmente a fenômenos?

É fácil formularmos um argumento de natureza "transcendental" para refutar o Neopirronismo. Encontro inspiração em três grandes nomes da filosofia de ontem e de hoje, são eles: Kant e a sua Refutação do Idealismo, Wittgenstein e o seu argumento contra a Linguagem Privada, e Kripke e Putnam com as suas teorias das referências diretas e o seu externalismo. O que todos eles tinham em comum? Rejeitavam a ideia de um mundo fenomênico fechado em si mesmo! A seguir arrolo os passos que uma refutação do Neopirronismo deve seguir: ${ }^{18}$

I. Segundo os Neopirrônicos, o fato que de algo apareça a todos (sensivelmente e descritivamente) em uma mesa de bar como água gelada garante que a proposição expressa pela frase "a água está gelada" seja ceticamente verdadeira

\footnotetext{
${ }^{18}$ Não se tratam de premissas de um argumento logicamente formalizado.
} 
porque se se adequaria não à essência ou a água em si, mas ante à realidade fenomênica da água, ou seja, ao que aparece a todos nós como água.

2. O pressuposto aqui é que o aparecer sensível e descritivo da água determine a referência do termo "água". "Água" faria referência a tudo aquilo que a nós todos aparece sensivelmente e intelectualmente como água, algo como líquido, insípido, incolor e inodoro, que abunda no planeta terra sob a forma de rios, lagos e oceanos e pode ser servido à mesa de um bar. ${ }^{19}$

3. Entretanto, o Neopirrônico não tem como deixar de reconhecer que: "O que nos aparece nos aparece aqui e agora. Mas muito do que nos aparece aqui e agora nos aparece aqui e agora como algo que antes já existia, independentemente de ter sido, ou não, por alguém observado ou pensado; ou como algo que continuará a existir no tempo futuro, independentemente também de nós e eventualmente nos sobrevivendo; ou ambas as coisas". (I993, p. I78, grifos meus)

4. Ora, a primeira dificuldade é a levantada por Kant: Como só temos a ver com "fenômenos", como nós poderíamos ordená-los no tempo? Como sei que aqui e agora nos aparece de uma certa forma já nos apareceu antes, que provavelmente nunca aparecerá depois ${ }^{20}$ Possível reposta (indireta) do Neopirrônico: "Estabilidade e regularidade relativas que não temos como não reconhecer, que o cético, como qualquer um, a cada passo e a cada momento reconhece. Os objetos do mundo exibem regularmente as mesmas propriedades e produzem costumeiramente os mesmos efeitos: ninguém contestará que o fogo derrete a cera, endurece a argila, queima a madeira”. (cf. A.M. VIII, 194-5). (2007, p. 199).

5. Ora, como também são fenômenos, a estabilidade e regularidade "relativas" também estão na ordem tempo e assim sujeitas à mesma indagação Kantiana: como determinar o que é estável e regular no tempo frente ao que instável e irregular se tudo é mero aparecer? Qual seria o tempo de duração de um aparecer estável?

6. Crítica kantiana: A distinção entre um aparecer estáveis e outro menos estável (relativas) jamais poderia resolveria o problema da determinação temporal, mas apenas algo absolutamente fixo no fluxo fenomenal. Dito isso,

${ }^{19} C f$. "O fenômeno é indubitável e incorrigível, ele não é objeto de disputa nem se póe em questão (cf. H.P. I, 20, 22; II, IO), ele não envolve a realidade das coisas concebidas (cf. H.P. II, IO). Dúvidas e disputas náo concernem ao "fenômeno", mas ao que se diz do "fenômeno", a algo ser conforme aparece (cf. H.P. I, I920), a uma não-evidência." (I993, p. IOO-IOI)

${ }^{20}$ Ora, se nada existe além do aparecer intersubjetivo, como poderia haver aparecer sem que haja mais ninguém a quem tal aparecer apareça? 
só nos resta uma explicação plausível: sabemos que o que nos aparece aqui e agora é o aparecer de anterior porque sabemos que ambos são fenômenos distintos de algo que nos aparece no espaço como permanente, mas que subsiste si mesmo! Ora, mas isso é exatamente o que o Neopirrônico questiona ao supor que o mundo do aparecer seja fechado em si mesmo. $\mathrm{O}$ argumento transcendental que proponho poderia se encerrar aqui. Mas vale a pena prosseguir.

7. A segunda dificuldade é levantada por Strawson (1959): Se só temos a ver com fenômenos, tenho suspendido o juízo sobre natureza corpos dos no espaço, como reidentificarmos fenômenos? Como posso saber que o que me aparece aqui e agora é numericamente idêntico ao que me apareceu anteriormente quando ambos aparecerem são qualitativamente idênticos tais como Castor e Pólux? Aqui a tentação do Neopirrônico seria apelar aqui à tese dos signos rememorativos. Entretanto, para que um fenômeno $\mathrm{x}$ me evoque à memória o fenômeno $\mathrm{y}$, tenho que ser capaz de identificalos independentemente da memória; caso contrário me verei às voltas com um vicioso regresso ao infinito.

8. A própria questão se nos referimos a um mesmo fenômeno em diferentes ocasiôes do tempo pressupóe a existência de um único sistema espaço-temporal, sem o qual a questão não faria sentido. Ora, se suspendemos os nossos juízos sobre a natureza dos corpos, e acreditamos apenas na estabilidade e regularidade relativa dos fenômenos, o que nos permitiria afirmar que nos encontramos em um mesmo sistema espaço-temporal? Voltando a Kant, se nada que permanece como numérico e qualitativamente idêntico independentemente das nossas afeçóes (pathé), ao invés de um único sistema espaço-temporal, teríamos vários sistemas incomensuráveis. Apenas a existência de algo que subjaza o fenômeno nos poderia certificar que estamos diante de um mesmo ou de um fenômeno distinto. Ora, mas isso é exatamente o que o Neopirrônico questiona ao supor que o mundo do aparecer seja fechado em si mesmo. O argumento transcendental que proponho poderia se encerrar aqui. Mas vale a pena prosseguir.

9. A terceira grande dificuldade é a mais contemporânea. Ela reside na forma como nos referimos a particulares dentro daquilo que o Neopirrônico denomina "linguagem comum" ou "linguagem vulgar". Segundo o Neopirrônico, no seu mundo fenomênico as palavras se referem aos fenômenos e nunca àquilo que subjaza ao fenômeno. Nesses termos, o que o Neopirrônico ignora solenemente é que ignoramos em grande parte tanto o ambiente físico quanto a comunidade linguistica a que pertencemos. E são eles quem 
determina a referência das palavras as coisas, em particular dos nomes comuns e próprios.

IO. Retomemos a situação original proposta tanto pelo Neopirrônico quanto pelo Neopositivista, mas no lugar de chope tenhamos o termo "água". Imaginemos filósofos reunidos alegremente a tomar água gelada em torno de uma mesa de bar. Prima facie, todos estariam de acordo que sobre o que estão a beber: água gelada. Suponhamos, adicionalmente, que um deles tenha sido abduzido por extraterrenos e tenha sido levado à célebre terragêmea onde a palavra "água" e seu análogo mental se referem a uma substância cuja fórmula química seria bastante complexa (abreviada por XYZ; cf. Puthnam, 1975). Lá, ele teria tomado o lugar do seu sósia sem que ninguém, nem ele próprio, tenha se apercebido da mudança. Ora, sem que se tenha ainda se ambientado ao local, ao proferir ou pensar como todos "a água está gelada”, ele estaria enunciando a mesma coisas que seus colegas? A resposta é claramente negativa. Enquanto todos estariam dizendo que $X Y Z$ está gelada, ele estaria dizendo equivocadamente que $\mathrm{H}_{2} \mathrm{O}$ está gelada. Por quê? Porque "água" na terra se refere a um substrato que possui uma essência que transcende o aparecer sensível e intelectual de água para alguém ou para todo um coletivo ("água” na terra sempre se refere a $\mathrm{H}_{2} \mathrm{O}$ e água é $\mathrm{H}_{2} \mathrm{O}$ em todos os mundos possíveis). ${ }^{21}$ Ora, mas é justamente isso que Neopirrônico nega ao supor que "água" faria referência a tudo aquilo que a nós todos aparece sensivelmente e intelectualmente como água: líquido, insípido, incolor e inodoro, que abunda no planeta sob a forma de rios, lagos e oceanos e pode ser servido à mesa de um bar. $\mathrm{O}$ argumento transcendental que proponho poderia se encerrar aqui.

II. Nesse ponto, o Neopirrônico poderia apelar a outros apareceres/fenômenos para se certificar que ao que no seu mundinho fenomênico "água" se refere a $\mathrm{H}_{2} \mathrm{O}$. Ora, mas recorrendo de fenômeno a fenômeno, estaríamos como sugere Wittgenstein a comprar novos exemplares de um mesmo jornal para nos certificarmos se o que o primeiro afirma é verdadeiro ou falso. Mais uma vez, a tentaçáo aqui seria apelar à tese dos signos rememorativos. Deste modo, contudo, caímos em um regresso ao infinito: fenômeno nos

${ }^{21}$ Muito ridicularizam a história de Putnam negligenciam o essencial. O importante na história é suposição tácita de que nunca conhecemos plenamente nem o ambiente físico nem a comunidade linguística nos quais nos inserimos. Por isso, o modo como as coisas nos aparecem nunca pode determinar a referência dos termos. 
remetendo a fenômeno. A única forma que possuímos de determos tal regresso é: (i) recorremos à essência do que aparece e (ii) à comunidade linguística à qual pertencemos.

I2. Redução ao absurdo: a premissa I é falsa. O que nos aparece a todos sensivelmente e descritivamente como água (i) não determina de forma alguma a sua existência no tempo, (2) é incapaz de ser reconhecido como tal, (3) nem é capaz de explicar a existência de um único sistema espaço-temporal e, por último, (4) é incapaz de determinar a referência dos termos mais importantes do que o Neopirrônico denomina "linguagem comum".

13. A fortiori, não pode haver "verdade cética ou fenomênica" nem tampouco "realidade cética ou fenomênica" uma vez a verdade supóe a concordância da palavra com algo que subjaz o fenômeno.

I4. Corolário I: Não é mais possível no mundo atual ser cético!

15. Corolário 2: a referência a essências das coisas em si mesmas que nos aparecem é a condição última de possibilidade da experiência humana.

I6. Corolário 3: a proposição enunciada pela frase "água é H2O" é uma verdade metafisicamente necessária, mas epistemicamente contingente ( $c f$. Kripke, 1980). Não obstante, a verdade da proposição "a referência de palavras a coisas é determinada sempre pelo que subjaz o fenômeno" é uma verdade sintética e a priori: uma verdade metafisicamente necessária, mas epistemologicamente também uma vez que se trata de uma condição de possibilidade da experiência humana em geral.

\section{Referências bibliográficas}

Aristóteles (1995). Aristoteles categoriae et liber de interpretatione. Minio-Paluello, L. (ed.). Scriptorum Classicorum Bibliotheca Oxoniensis; oxonii; E Typographeo Clarendoniano.

Bayle, P. (2005). Dictionnaire Historique Et Critique De Pierre Bayle. Londres: Elibron Classics (Reprodução do Dictionnaire Historique et Critique. Paris: Desoer, I820).

Barnes, J. (1982/1998). “The Beliefs of a Pyrrhonist”, in: Frede, M. \& Burnyeat, M. (eds.) The original sceptics: a controversy. Indianapolis/Cambridge: Hackett.

Burneyat, M. F. (1984). "Can the skeptic live his skepticism?", in: Burnyeat, M. (ed.). The skeptical tradition. Berkeley: University of California Press, p.II7-I48.

Carnap, R. (1928). Der logische aufbau der welt. Hamburg: Meiner Verlag.

Carnap, R. (1980). "Pseudoproblemas na filosofia", in: Os Pensadores, Schlick e Carnap. São Paulo: Abril Cultural. 
Cassirer, E. (1929/1957). Philosophie der Symbolischen Formen, v. 3: Phänomenologie der Erkenntnis, in: ecw, vol. 13; op. cit.: The philosophy of symbolic forms, v. 3: The phenomenology of knowledge. Tradução de Ralph Manheim. New Haven: Yale University Press.

Chisholm, R. M. (194I). “Sextus Empiricus and Modern Empiricism”, in: Philosophy of science, v. 8, n. 3, p. 37I-383.

Fortuna, S. (200I). "Ii metodo della diagnosi in Galeno", in: Elenchos: Rivista di Studi Sul Pensiero Antico, 22 (2), p. 28I-304.

Frede, M. (1987). “The skeptic's beliefs”, in: Essays in Ancient Philosophy. Oxford: Clarendon Press, p.I79-200.

Hegel, G. W. F. (2000). "On the relation between scepticism and philosophy. Exposition of his different modifications and comparison of the latest form with the ancient one", in: Di Giovanni, G. and Harris, H. S. (eds.), Between Kant and Hegel. Texts in the development of post-kantian idealism. Trad. de Harris, H. S. Indianapolis: Hackett.

Hume, D. (1992). A Treatise of Human Nature. Selby-Bigge, 1. A. (ed.) 2. ed. Oxford: Clarendon Press.

Kant, I. As citações são extraídas da Academia Prussiana de Berlim. Gesammelte Schriften, ed por Preussische Akademie der Wissenschaften, Berlim de $1902<\mathrm{AA}>$. As exceçôes são a Crítica da Razão Pura, Primeira Edição A e a segunda edição B, com citação da Felix Meiner, Hamburgo, 1956, e a Anthropologie in Pragmatischer Hinsicht. Felix Meiner Verlag, Hamburgo, 2000.

Kripke, S. (1980). Naming and Necessity. Cambridge, Mass.: Harvard University Press.

Pereira, R. (2020a). "Disentangling cartesian global skepticism from cartesian problematic external-world idealism", in: Archiv für Geschichte der Philosophie, $\mathrm{IO} 2(2)$.

Pereira, R. (2020b). “The real target of Kant's refutation”, in: Kantian Journal, Immanuel Kant Baltic Federal University (IKBFU), 38(3).

Pereira, R. (2020c). "Cassirer and Kant on unity of space and the role of imagination”, in: Kant-Yearbook, vol. I2: Issue I.

Porchat, O. (1993). Vida comum e ceticismo. São Paulo: Brasiliense.

Porchat, O. (2007). Rumo ao ceticismo. São Paulo: Unesp.

Porchat, O. (20I6). "Meu ceticismo", Discurso v. 46, n. 2 (2016), p. 7-36.

Putnam, H. (1975). "The meaning of 'meaning”, in: Minnesota Studies in the Philosophy of Science, vol. 7, p. I3I-I93.

Sexto Empírico. (1976). Sextus Empiricus, 4 vol.. Bury, R. G. (ed.) The Loeb Classical Library. Cambridge, Mass: Harvard University Press/Londres: 
Schlick, M. (1973). "Sentido e verificação", in: Os Pensadores, Schlick e Carnap. São Paulo: Abril Cultural.

Strawson, P. F. (1959). Individuals: An Essay in Descriptive Metaphysics. Londres/Nova York: Routledge. 